\author{
И. И. Макеева \\ Институт русского языка им. В. В. Виноградова РАН \\ (Москва, Россия) \\ irinamakeeva2007@mail.ru
}

\title{
ПОРЯДОК СЛОВ В ГРУППЕ «ЛИЧНАЯ ФОРМА ГЛАГОЛА + ПРЯМОЕ ДОПОЛНЕНИЕ» В РИТОРИЧЕСКИХ ПРОИЗВЕДЕНИЯХ КИРИЛЛА ТУРОВСКОГО
}

Статья посвящена исследованию расположения глагола и прямого дополнения в Словах древнерусского писателя XII в. Кирилла Туровского (по списку XIV в.). Для авторского текста характерна препозиция глагола, хотя часто встречается его постпозиция. Такое расположение глагола и дополнения обусловлены несколькими факторами, которые рассматриваются в статье.

Ключевые слова: Слова Кирилла Туровского, древнерусский язык, синтаксис, порядок слов, глагол, дополнение.

1. В многочисленных исследованиях, посвященных сочинениям древнерусского писателя XII в. Кирилла Туровского, неоднократно рассматривались языковые особенности текстов. Синтаксис произведений оставался и остается вне поля зрения. Между тем именно особенности построения словосочетаний и предложений демонстрируют специфику языка и стиля Кирилла.

В этом отношении перспективно исследование восьми риторических произведений писателя, которые, хотя и принадлежат к одному жанру, оказываются довольно разными по синтаксическим параметрам. Среди них есть как собственно похвальные Слова («Слово на Пасху», «Слово на Вознесение», «Слово в неделю цветоносную»), так и имеющие сюжетную основу («Слово о снятии тела Христова с креста», «Слово памяти отцов Никейского собора»). Разнообразна их тематика: они написаны на праздники начиная с Вербного воскресенья и кончая седьмой неделей после Пасхи, когда отмечается память отцов-участников I Вселенского Никейского собора. Все это сказывается на содержании и на используемых автором языковых средствах.

Общим для риторических произведений писателя является немногочисленность сложноподчиненных предложений. Преобладают цепочки предикаций, которые можно рассматривать как простые предложения или как части сложносочиненного предложения. 
1.2. Проведенное ранее изучение расположения атрибута в именных группах в риторических сочинениях Кирилла показало, что для него характерна препозиция. В этом отношении Слова древнерусского писателя оказываются наиболее близкими к источнику совершенно другого рода - «Русской Правде» [Макеева 2018; 2019]. Среди именных групп с атрибутом значительную долю составляют словосочетания со словоформами в винительном падеже прямого объекта. При этом нередко встречается дистантное расположение атрибута, которое возникает за счет его отделения от существительного личной формой глагола. Таким образом, именные группы с атрибутом оказываются тесно связанными со словосочетаниями «личная форма глагола + прямое дополнение». И в некоторых случаях можно говорить о влиянии первых на вторые при выборе расположения компонентов словосочетаний.

1.3. В качестве прямого дополнения выступают имена существительные, иногда - субстантивированные причастия и прилагательные, расположение которых относительно глагола варьируется. Дополнение, являющееся личным местоимением, обычно находится в постпозиции по отношению к глаголу, а остальные местоимения - в препозиции. Случаи отступления от такого расположения встречаются, но редко.

В старших списках Слов Кирилла Туровского, датируемых XIII-XIV вв. ${ }^{1}$, как постановка атрибута, так и расположение прямого дополнения остаются неизменными. Расхождения встречаются, но они единичны ${ }^{2}$. Намеренные изменения порядка слов предпринимали только некоторые писцы в поздних списках. В рукописях XVI-XVII вв. возможны замены глагольных форм: вместо причастия употребляется личная форма глагола и наоборот. В старших списках в составе словосочетания «личная форма глагола + прямое дополнение» такие расхождения единичны.

Расположение личной формы глагола и прямого дополнения рассмотрено в восьми риторических произведениях Кирилла Туровского по списку Увар-589 XIV в. ${ }^{3}$

${ }^{1}$ Рукопись РНБ, F. п. І. 39, Сборник, 2-ая половина ХІІІ в. (далее Толст-39); рукопись ГИМ, собр. Уварова, №589, 4을 Сборник, XIV в. (далее Увар-589); рукопись ГИМ, Чудовское собр., №20, Сборник, XIV в. (далее Чуд-20).

2 Особо следует сказать о списке Тр-9 XV в. (РГБ, собр. Троице-Сергиевой лавры, № 9, Сборник). В эту рукопись вошли семь риторических произведений Кирилла Туровского: «Слово в неделю цветоносную» (л. 32 об.), «Слово на Фомину неделю» (л. 68), «Слово о снятии тела Христова с креста» (л. 73 об.), «Слово о расслабленном» (л. 81), «Слово о слепце» (л. 96 об.), «Слово на Вознесение» (л. 102), «Слово памяти отцов Никейского собора» (л. 111 об.). Два первых и два последних текста в Тр-9 имеют незначительные отличия от старших списков, как и начало «Слова о снятии тела Христова с креста» и конец «Слова о слепце». Однако примерно с л. 75 в Тр-9 начинается редакторская правка: дополнения фраз, замена лексики, другой порядок слов. Аналогичные изменения представлены в «Слове о расслабленном» и в большей части «Слова о слепце» (примерно до л. 100).

3 Это единственный из старших списков, содержащий все восемь текстов, которые находятся на лл. 224 об. - 283. В приводимых примерах для большей ясности при описании структуры предикаций и особенно периодов упрощена орфография и частично расставлены знаки препинания. 
Порядок слов в группе «личная форма глагола + прямое дополнение», обозначаемый как VO или OV (где V - личная форма глагола, O - дополнение-существительное), в риторических произведениях Кирилла Туровского представлен следующим количеством примеров.

\begin{tabular}{|l|c|c|}
\hline \multicolumn{1}{|c|}{ Произведение } & VO & OV \\
\hline «Слово памяти отцов Никейского собора» (СПОНС) & 35 & 19 \\
\hline «Слово о слепце» $(\mathrm{CC)}$ & 28 & 31 \\
\hline «Слово о снятии тела Христова с креста» (ССТХК) & 58 & 38 \\
\hline «Слово на Пасху» (СП) & 31 & 21 \\
\hline «Слово в неделю цветоносную» (СЦ) & 18 & 22 \\
\hline «Слово на Фомину неделю» (СФН) & 32 & 49 \\
\hline «Слово на Вознесение» (СВ) & 38 & 13 \\
\hline «Слово о расслабленном» (СР) & 26 & 27 \\
\hline
\end{tabular}

В «Слове о снятии тела Христова с креста» группа «личная форма глагола + прямое дополнение» встречается чаще остальных не только потому, что это самый большой текст. На частотность группы влияет содержание: в основу этого произведения положены события Страстной пятницы и субботы. «Слово памяти отцов Никейского собора» ненамного меньше, но в силу специфики его содержания в нем чаще отмечаются именные группы с атрибутом.

В целом в риторических произведениях Кирилла Туровского преобладает препозиция глагола. В четырех текстах (СС, СЦ, СФН, СР) чаще встречается постпозиция глагола, и в «Слове на Фомину неделю» количество таких случаев значительно превосходит показатели остальных трех текстов.

При подсчетах учтены цитаты из Священного Писания, число которых в риторических произведениях древнерусского писателя довольно велико. Изучение расположения атрибута показало, что при цитировании Библии он находится в постпозиции [Макеева 2018: 90]. Прямое дополнение в цитатах может находиться как в постпозиции, так и в препозиции: пригвоздиша руц̧ъ мои и нозъ мои, и въдаша въ ядь мою золчь (СП; Псал. 21: 17, 68: 22); сберу на ня злая и стрьльл моя скончаю в них (СС; Второзак. 32: 23). Кирилл сохранял то же расположение дополнения и глагола, какое было в первоисточнике, хотя возможно изменение места компонентов ${ }^{5}$. Сложность заключается в том, что Кирилл использовал ветхозаветный и новозаветный тексты достаточно свободно. Он мог соединить в одной цитате фрагменты из разных библейских книг или использовать аллюзию (парафраз), а также включал мелкие фрагменты и отдельные словосочетания из Священного Писания непосредственно в авторское повествование. Обычно цитаты, подчас

Расхождения в порядке слов и в отдельных словоформах с самым ранним, но неполным списком Толст-39 оговариваются особо.

${ }^{4} \mathrm{~B}$ скобках здесь и ниже приведены сокращенные названия произведений, используемые в примерах.

${ }^{5}$ Случай такого изменения в ряду других отличий цитат в Словах Кирилла Туровского от первоисточника приведен в [Рогачевская 1992: 188]. 
вовсе не являющиеся таковыми в строгом смысле слова, вводятся разными формами глаголов рещи и глаголати; указание на источник может быть как точным, так и самым общим (пророкъ); нередко вместо этого назван персонаж, которому при-

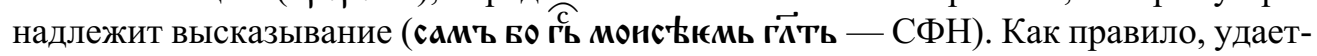
ся отделить авторский текст от использованного первоисточника, хотя иногда это нелегко сделать ${ }^{6}$. Ввиду всего вышесказанного корректнее не производить подсчет случаев VO и OV без учета библейских цитат.

2. Преобладание препозиции глагола, хотя и незначительное, позволяет предположить, что порядок VO был обычным и нейтральным. Это положение подтверждается аналогичным следованием компонентов в Новгородской I летописи, где порядок VO встречается вдвое чаще, чем OV [Пичхадзе, Родионова 2011: 151].

2.1. Расположение объекта-существительного в препозиции в Словах Кирилла Туровского обусловлено несколькими факторами, значимость и частотность которых сильно варьируются. Из них прежде всего надо назвать рематизацию глагола и вхождение группы «личная форма глагола + прямое дополнение» в придаточное предложение определенного вида. Эти факторы можно отнести к стандартным, их роль отмечается в разных текстах.

Для произведений Кирилла Туровского важнейшим фактором, влияющим на расположение личной формы глагола и прямого дополнения, является структура фрагмента текста (периода), в которой реализуется риторическая стратегия писателя 7 . Помимо общей структуры, порядок следования компонентов в группе «личная форма глагола + прямое дополнение» может быть обусловлен противопоставлением и сопоставлением соседних предикаций, их параллелизмом или, напротив, разным построением, наличием обобщающего понятия при нескольких предикациях, нахождением рассматриваемого словосочетания в начале текста или структурно-смыслового фрагмента. Значимым для расположения компонентов

${ }^{6}$ Одним из подобных примеров является следующий фрагмент: $\boldsymbol{w}$ нємжє прорєчє кангафа. ТОМУ КАННОМУ ОУМРЕТН ЗА ВеСЬ МНрЪ [За ВЬСЬ МНрЪ ОГМРЕТН ТОЛСТ-39]. НЕ ПРОСТО СЕГО ПРОрЕЧЕ.

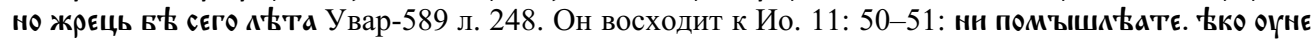

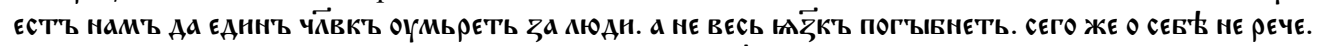
HЪ арХиерен СЪ А 1998: 55]. В связи с этим следует упомянуть точку зрения Ф.Н. Двинятина, который Слова Кирилла отождествлял с «традиционным текстом», то есть со Священным Писанием; см. [Двинятин 1995].

${ }^{7}$ Кирилл Туровский является продолжателем традиций византийского торжественного красноречия, используя характерные для него приемы. Как всякий талантливый писатель, он делает это по-своему. Ю.К. Бегунов в сопоставительном анализе «Слова о снятии тела Христова с креста» Кирилла и Слова Григория Цамблака на ту же тему показал, что ее выбор лишь отчасти предопределяет композиционные приемы, которые тесно связаны со стилистическими средствами [Бегунов 1971]. Риторическая стратегия древнерусского писателя складывается из многих составляющих: особенностей композиции, связанной с темой, используемых стилистических средств, причем важно, как, по словам Ю.К. Бегунова, стилистические приемы «работают на содержание». В риторическую стратегию писателя входит и отбор языковых средств, также «работающих на содержание». 
оказывается принадлежность группы «личная форма глагола + прямое дополнение» к несвободным словосочетаниям, а также случаи, когда она представляет собой figura etymologica. Лексическое значение или принадлежность компонентов к определенному разряду, влияющие на постановку атрибута, при выборе расположения глагола и прямого дополнения имеют значение лишь иногда. Частными случаями являются особый порядок в конструкции с двойным винительным (accusativus duplex) и препозиция дополнения и постпозиция глагола в вопросительных предикациях с местоимениями кыи и какъ.

3. Часть случаев, когда личная форма глагола находится после дополнения, обусловлена актуальным членением предложения. В постпозитивном расположении глагола можно предполагать его актуализацию ${ }^{8}$, или рематизацию: вctx же гласbl окончаваеть Павель глаголя... (СВ); кылждо бо рабъ своего господина хвалить (СЦ); и всь недугъ мои обратиль есть въ здравие (СР); Евжинъ плачь на радость преложи (ССТХК). См. также раздел 8.

4. Явно выраженной зависимости расположения глагола и дополнения от того, находится ли группа в главном предложении или в придаточном, не наблюдается. Тем не менее в немногочисленных определительных и условных придаточных, имеющих рассматриваемую конструкцию, часто отмечается постпозиция глагола: ...на муку волную, еюже ада попра, адама изведе и сьмьрть попра (ССТХК); ... иже Костянтина иъсаря от проказы очисти и многа инь чюдеса створи; ...иже сльпию очи словом отверзе и нъмому молитвою глаголати створи (СПОНС); помысльи, иже... душеполезныя плоды гобьзують; ... в нюже поновленье празнуемь въскресения; ... имаже сльпьмь очи отверзохъ и глухымъ слухъ даровахъ (СФН $)^{9}$; аще и младеньиъ изби...(Там же); аще бо и брамно обрящю... (СР); ... идъже вь своя дъти бъсомъ закаласте $(\mathrm{CC})^{10}$. Аналогичная картина представлена в Новгородской I летописи; в «Пчеле» равно употребителен порядок VO и OV [Пичхадзе, Родионова 2011: 156, 149].

В придаточных предложениях с побудительной частицей $\partial a$ также чаще отмечается постпозиция глагола; см. раздел $\mathbf{5 . 3 .}$

Другие виды придаточных предложений немногочисленны, поэтому нет достаточных сведений о тенденции расположения в них личной формы глагола и прямого дополнения : ... дондеже и чермъное море проидоша (СФН); ... яко отверзе коли кто сльпу очи рожену (СС); яко свьщаша свьть золь (СП); почесть творяще ему, егда и Лазаря из гроба възва и от мертвхь его въскрьси (СЦ); ...прорече, егда призва... ересьскыя священики (СПОНС).

5. Целесообразно сначала рассмотреть, как могут быть построены две и более соседних предикации в составе структурно-смысловых фрагментов текстов (периодов). При этом необходимо учитывать даже те предикации, которые

8 Об актуализации в связи с синтаксическим членением см. [Ковтунова 1976: 67-76].

9 Однако в другом придаточном с тем же глаголом и дополнением обратный порядок: ... яко отверзе коли кто сльпу очи рожену (CС).

${ }^{10}$ Остальные примеры с таким же порядком см. ниже в составе анализируемых периодов. Предикации с порядком VO см. в разделах 5.2, 5.4.1. 
не имеют в своем составе группы «личная форма глагола + прямое дополнение», поскольку общий принцип препозиции или постпозиции глагола распространяется и на них ${ }^{11}$.

5.1. Один тип построения соседних предикаций основан на параллелизме, то есть в каждой из них глагол будет находиться или в начале, или в конце: Како тя терниемь вънчаша, и золчи с оцтомь напоиша, и еще пречистая ти ребра копиемъ прободоша (ССТХК); Се бо наша бользни понесе, и за ны пострада, и раною его вси исиъльхомъ (Там же); днесь апостоли на жребя своя ризы възложиша, и Христось верху ихъ въсьде (СЦ); падшаго преступлениемь възведе, всьхь бо грьхы вземь на кресть пригвозди (СП); остави небеса и позвавшаго на ня Христа и обратися в преисподняя ада с прельстившимь его змиемь (СПОНС). Хорошо демонстрирует параллелизм следующий пример, где в каждой предикации на последнем месте находятся соотносительные във $а д ъ-в$ раи с предшествующей

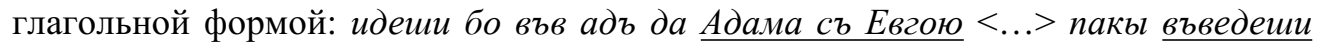
в раи (ССТХК).

Параллелизм распространяется и на целый период: днесь бо Христосъ своя раздаваеть комуждо дары: лаеть апостоломь святыи свои духъ, въводить душа святыхъ пророкъ въ небесное ияарство, раздъляеть своимь угодникомь горняго града обители, отверзаеть праведникомь раи, вънчаеть страдавшая за нь мученики, посьлаеть страстотерпиемь чюдес благодать, даеть святителемь душеполезная прошения, отпушаеть грбиникомь прегрьшения, милуеть вся творящая волю его и хранящая заповьди его, посылаеть благовьрнымь княземь нашим здравье телесем и душамь спасенье и врагом одольние, утвержаеть иеркви, обогащаеть иерковники, честны творить служащая ему ерья и дьяконы, освящаеть манастыри, прославляеть игумень, укрьпляеть на терпьнье мнихи, благословляеть вся крестьяньл... (СВ). Уникальность этого большого периода заключается в том, что в каждой предикации имеется глагол и прямое дополнение, которые расположены в одном и том же порядке $\mathrm{VO}^{12}$.

5.2. В другом - противоположном - типе построения соседних предикаций глагол меняет свое место в каждой из них: днесь горы и холми точать сладость, удолия и поля плодь господеви приносять (СЦ); днесь народи постилають господеви ризы своя, друзии же от древа ломяще вътви постилаху (Там же); обнажи предо всъми своя ребра и гвоздиньныя язвь на руку и ногу показаеть Фомь (СФН); вънчаимъ, братие, иарицю днемъ и дары честны с вьрою тои принесемъ (Там же); Иисусь Христось единь ополчися на вся бъсовьскыя силь и власти темныя испроверже (СВ); вселестьное искоренисте тернье, и богоразумье во вся человьки присадисте, и олядъвиую грьхи землю евангельскымь раломь въздъласте (СПОНС).

11 Возможно, надо учитывать и причастные предикации, так как причастия нередко выступают в роли второстепенного сказуемого.

12 Поэтому в «Слове на Вознесение» количество примеров с препозицией глагола почти в три раза больше по сравнению с постпозицией. 
Подобное изменение порядка слов в соседних предикациях можно рассматривать как разновидность хиазма ${ }^{13}$, благодаря которому Кириллу Туровскому удается избежать однообразия и монотонности ${ }^{14}$.

На сочетании параллелизма и хиазма древнерусский писатель нередко строит целые периоды, как, например, в «Слове на Фомину неделю»: вижю руиь твои (VO), имаже преже створи всю тварь (VO), и раи насади (OV), и человька созда (OV), и имаже благослови патриархы (VO), имаже помаза ияары (VO), имаже освяти апостоль (VO); в «Слове о слепце»: ... сынове Ияковли погубити мыслять пришедъшаго, садукъи прозрьвшаго на судище влекуть (OV), иродьяне сборище совокупляють (OV).., книжници изумьвиеся пытают родителю (VO).., старии укаряють в суботу отверзшаго очи (VO) .., фарисъи льстяще народь хулять чюдотвориа (VO), жеризы изгонять от сборища помилованаго богомь (VO), архиерьи претять прозрьвшему да похулить просвьтивщаго и (VO); в «Слове о расслабленном»: се в тобъ всего Адама мозоли ицълихъ (OV), и падиа преступленьемь възведохъ (OV), и всеродную того клятву отяхъ (OV), отмыхъ скверну всякого прегрвшенья... (VO), взискавъ обрвтохъ шедшаго в пути... (VO), обязах раныл уязвенаго бъсовьскыми разбоиники (VO), възлияхъ на язвы его моея крови вино и масло (VO).

5.3. Особым образом построен период в «Слове о снятии тела Христова с креста». Он состоит из нескольких пар предикаций. В первой предикации каждой пары речь идет о событиях последних дней земной жизни Христа и о его смерти, а во второй - о том, с чем это соотносится. За исключением двух случаев, вторая предикация в паре является придаточным предложением с частицей $\partial a$. Рассматриваемые словосочетания «личная форма глагола + прямое дополнение» находятся в каждой второй парной предикации. Расположение глагола и дополнения в них варьируется, хотя чаще отмечается постпозиция глагола ${ }^{15}$. В приведенном ниже тексте для наглядности каждая пара предикаций расположена на новой строке и разделена знаком - (тире):

На трости губою оцта съ золчию вкуси - да загладитъ рукописание человьчьскихъ съгрьиении (VO);

${ }^{13}$ О хиазме в русском литературном языке XVIII в. см.: [Ковтунова 1969: 78-79].

${ }^{14} \mathrm{Cp}$. пример с одинаковым порядком глагола и прямого дополнения, но разным расположением атрибута: тамо побъди власти темныя крьстомь, изведе всероднаго адама со всъми... Намного реже, но все же встречаются примеры параллелизма и хиазма в расположении атрибута.

${ }^{15} \mathrm{Cp}$. порядок в следующих придаточных, часть из которых приведена при анализе других факторов, влияющих на расположение глагола и дополнения: да ти своея бользни напасть исповъдъ; $\ldots$ да богомь человька створю $(\mathrm{CP}) ;$ претять ... да похулить просввтившаго и (СС); ... да человькъмь сладость и иьркви потребная подасть; ... да очистиши оскверньшююся землю... да освятиши человьчское естьство (СФН); .. да змия погубить и человъка спасеть (ССТХК); носяще араматы да тыло помажуть Иисусово (СП); ... да .. в руиъ господни душю предамь (СПОНС); ... да послеть и намъ пресвятыи свои духъ (СВ). В «Пчеле» в таких же предложениях господствует порядок VO; см. [Пичхадзе, Родионова 2011: 150]. 
Копиемь в ребра прободенъ бысть - да пламеньное оружие отложить, бранящее человькомъ входа в раи (OV);

Кровь с водою ${ }^{16}$ из ребрь источи (OV) - имаже телесную всю скверну очистивъ и душа человьча освятиль есть (OV);

Связань бысть и терниемь въньчань - да разрьиить от узь дьяволь человькы (VO) и терние прельсти вражия искоренить (OV);

Солнце помрачи (OV), и землею потрясе, и твари всеи плакатися створи да адьская разрушить скровища (VO), и тамо сущихъ души свъть видъша (OV);

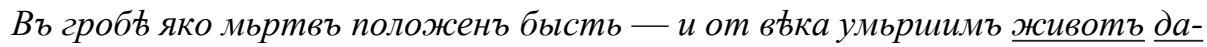
рова $(\mathrm{OV})$;

Каменемь с печатми утвержень - да адова врата и верея от основания скрушить (O и $\mathrm{OV})$.

Таким образом, как построение отдельных предикаций, обычно двух соседних, так и предикаций в составе периода, а в них - порядок слов в группе «личная форма глагола + прямое дополнение» зависит от риторической стратегии, которой следует Кирилл Туровский.

5.4. Особого внимания заслуживает «Слово на Фомину неделю», в котором количество употреблений глагола в постпозиции, а прямого объекта - в препозиции намного больше, чем в других Словах. Причем основной массив таких примеров приходится на ту часть произведения, в которой Кирилл изображает картины весенней природы, сопровождая их символико-аллегорическими толкованиями. Именно в этой части сначала М.И. Сухомлинов, потом В. В. Виноградов ${ }^{17}$ находили сходство со Словом Григория Богослова (Назианзина) с толкованиями Никиты Ираклийского «В новую неделю, и о весне, и о святом мученике Маманте, и о обновлении» (начало: «Поновления чтете...»).

Однако древнерусский писатель не повторяет византийский первоисточник. Достаточно двух примеров, чтобы увидеть больше различий, чем сходства:

Слово Григория Богослова: ... нынъ лунъ кругъ прозрачьнъи; Толкования Никиты Ираклийского: Нынъ лунъ кругъ прозрачнъи есть себе, зимъ бо темнъиши есть въздуха ради дебелости. Слово Кирилла Туровского: Нынъ луна с вышняго съступивши степени большему свътилу честь подаеть. Уже ветхии закон по писанию преста с суботами, и церковь Христову закону с неделею честь подаеть;

Слово Григория Богослова: И рыбарь глубинь съзираеть, и мръжу очищаеть, и на каменех съдить; Толкования Никиты Ираклийского: И рыбарь глубины съзираеть и очищаеть мръжу, и горь на камени съдя ловит. Слово Кирилла Туровского: Рыбари глубину божия вочеловъчения испытавще полну ичерковную мрежу ловитвы обрытають.

16 Так в Толст-39; в Увар-589 свою вместо с водою.

17 См. [Сухомлинов 1858: 29-33; Виноградов 1915: 117-128]. 
Даже если обнаруживается совпадение отдельных слов (мрьжа, рықарь, глоувнна и др.) и близость некоторых фраз ${ }^{18}$, предполагать влияние византийского произведения на порядок слов в группе «личная форма глагола + прямое дополнение» в сочинении древнерусского писателя нет оснований, ср. у Кирилла Туровского: и се уже огради сладку подавають воню; в Толкованиях Никиты Ираклийского: и овощчници слатку воню посьлають.

5.4.1. В целом часть «Слова на Фомину неделю» Кирилла Туровского, о которой идет речь, построена по определенной схеме ${ }^{19}$, но она из-за большой величины фрагмента неочевидна. Рассматриваемая группа находится как в описаниях природы, так и в их символико-аллегорических толкованиях, и содержащие ее предикации не всегда являются соседними. Тем не менее обычно дополнение находится в препозиции, а глагол - в постпозиции ${ }^{20}$. Приведенные ниже примеры включают предикации, находящиеся в картинках природы и относящихся к ним толкованиях ${ }^{21}$; словосочетания с редким в этой части порядком VO снабжены соответствующей пометой:

небеса просвьтишася ... свътльмьвъздухомь славугосподню исповьдають..; апостоли же ... святымь духомь осънени воскрьсение Христово ясно проповьдають;

солнце красуяся к высоть въсходить и радуяся землю ${ }^{22}$ огрьваеть; взиде бо праведное солнце от гроба Христось, и вся вьруюшая к нему спасаеть; луна с вышняго съступивши степени болшему свьтилу честь подаеть; ... иььккы Христову закону с недьлею честь подаеть;

днесь весна красуется... и горнии ${ }^{23}$ вътри тихо повъвающе плоды гобьзу$\underline{\text { ють }}$, и земля съмена питающи зеленую траву ражаеть; весна убо есть

18 Ср. у Кирилла Туровского: Нынъ небеса просветишася, темных облакъ яко вретищь совлекошася; у византийского автора: Ньль небо свътлье, темных облакъ яко одежда чръны съвлькся.

19 Она состоит из двух больших фрагментов, а те, в свою очередь, из нескольких периодов,

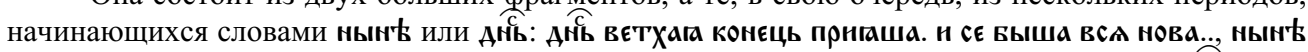

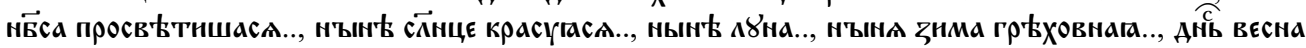

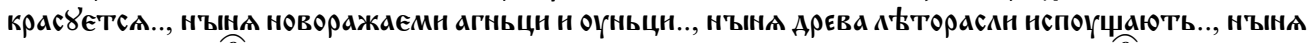

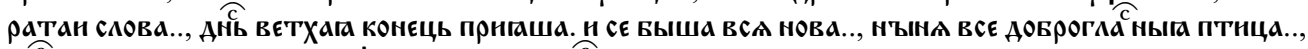

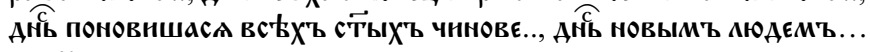

20 В «Слове о расслабленном» в монологе Христа есть небольшой фрагмент, в котором он говорит о созданном ради человека мире. Здесь глагол тоже находится в постпозиции: тебъ всю тварь на работу сътворих; небо и земля тобъ служита, оно влагою, а си плодомь; тебе ради солнце светомь и теплотою служить и луна съ звъздами нощь объляеть; тебе дъля облаци дъждемь землю напаяют и земля всяку траву съмениту и древа плодовитая на твою службу въздрашают; тебе ради рькы носять, пустыни звъри питаеть.

21 В их число не включены предикации с двойным винительным и с дополнением Христос, бог, господь, которые рассматриваются отдельно.

22 Такова правильная форма слова, зафиксированная в Толст-39.

23 Это прилагательное читается в Увар-589 и близких к нему списках. У Кирилла Туровского было бурнии, что и представлено в большинстве рукописей. 
красная въра Христова ${ }^{24}$, яже крьщениемь поражаеть человъчьское пакьестьство (VO); бурнии же вътри грьхотворении помьсльл, иже... душеполезныл плоды гобьзують; земля же естьства нашего... духь спасения ражаеть;

новоражаемии агньции быстро путь перущее скачють... млеко учения cbcymb;

древа льторасли испущають и цзвтти благоухания процвитають, и се уже огради слатку подавають воню (VO);

ръкы апостольскыя рыббл наводняються, и язычныл рыбы плодь пущають, и рыбари глубину божия вочеловъчения испьтавше полну изьрковную мръжю ловитвы обрвтають;

мнишьскаго образа трудолюбивая пчела... ангельи и человъки удивляеть, и си на иявтты излетающе медвеныи соть стваряють, да человъкъмь сладость и цуьркви потребная подасть;

постьници и пустьньници от рукы господня труда мьзду прияма въ горнимь грады съ святыми веселятся.

5.4.2. Количество примеров с постпозицией глагола и препозицией дополнения в «Слове на Фомину неделю» пополняет еще один фрагмент - обращение писателя к пастве. В коротком периоде имеется пять случаев такого порядка: въруемъ Христу богу нашему, распенъшему поклонимся, въскресшаго прославимь, явлешемуся апостоломь въруимъ, и своя Фомь показавшаго ребра въспоимъ, пришедшаго оживить нась похвалимъ, и просвьтившаго ныл исповьдаемъ, всьхь благъ подавшаго намъ обилие възвеличимъ... .

5.4.3. Такой же порядок слов Кирилл Туровский использует в обращении к пастве в другом своем сочинении — «Слове в неделю цветоносную». В нем в бо́льшей первой части обращения первое место в предикациях занимает глагол, в том числе и в группах «личная форма глагола + прямое дополнение» (за исключением последнего придаточного предложения): придъмъ поклонимся ему; припадемъ ему яко блудница мысльно; останъмся якоже и она от зльхъ дъль; изльимьл яко мюро на главу его вьру и любовь нашю; изидемь с любовью яко и народи вь стрттение ему; сломимъ гнъводержание; въскликнемъ молитвами и безлобиемъ яко младении; преидемъ милостьнми къ нищимъ; въсльдуимъ смирениемь, постомь, бдъниемь и божественымь покаяниемь; уготоваимь, яко и горлицю, смьрениемь душа наша; поидемъ съ идушимь на страсть волную; возмемь крест свои претерпьниемь всякоя обиды; распнемся браньми ко грвху; умьртвимъ похоти телеснья; въскликнемь осанна въ вышнихъ, благословенъ еси пришедыи на муку волную, еюже ада попра, адама изведе и съмьрть попра. Далее следует фраза до сдє жє слово шкратнвше, устанавливающая границу между первой и второй частями обращения. После нее меняется общая тематика призывов и их построение - теперь глагол оказывается в постпозиции (кроме последней предикации): nъсньми яко ц̧въты святую йьрковь вьнчаемъ и празникъ украсимъ; богови хвалословление въсльмъ; да спасителя

${ }^{24}$ В этой фразе по спискам варьируется порядок слов, из-за чего меняется ее смысл. 
нашего възвеличимъ; да радостьно празновавше в мирь достигнемъ тридневнаго въскрьсения.

Короткое обращение к пастве есть также в заключительной части «Слова на Вознесение»: придъмъ и мы, братье, въ святую иььрковь, възвеличимъ Христа бога нашего, давшаго ны животь прославим и по сихъ объщавшаго небесное ичарство възнесемъ имя его вкуnt... Чередование предикаций с разным порядком слов в рассматриваемой группе и краткость обращения лишают его той стилистической выразительности и потенциального эмоционального воздействия на паству, которой обладают другие аналогичные фрагменты риторических произведений Кирилла Туровского.

6. Семантика сопоставления или противопоставления - следующий по значимости фактор, оказывающий влияние на расположение личной формы глагола и дополнения ${ }^{25}$. В подобных предикациях дополнение находится в препозиции, а глагол в постпозиции.

6.1. Обычно семантика сопоставления и противопоставления реализуется в одной предикации, в паре предикаций или в двух находящихся рядом парах: $\partial а$ не токмо Иисуса, нъ и Лазаря погубять (СЦ); она купьль многое ${ }^{26}$ приимающи, единого исиъляше (СР); Христос въскрьсе, а жерции и фарисъи стражъ мьздять (СП); в жидьхь бо чюдеса створи, а языкомь благодать и спасение дарова (СЦ); израиль отречеся позвавшаго въ въчную жизнь, а языки въровавшая въ небесное иарство въведе (Там же); Она бо от змия свьть прия, вы же от ангела слово сльшита. Радость вамь глаголю, вы же спасение миру проповьдите (СП).

6.2. На основе такой же семантики может быть построен период: Иисусь Христосъ распинаемъ бъ яко человъкъ и яко богъ <... яко человъкъ възпивъ испусти $\underline{\partial x ъ}$, нъ яко богъ землею потрясе и камение распадеся; яко человькъ в ребра ударяемъ, но яко богъ завьсу перваго закона полма раздьра; яко агнець кровь свою исто-

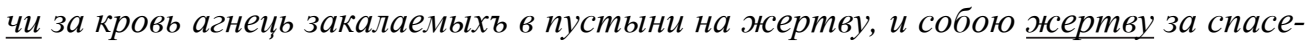
ние всего мира богу и отцую принесе; яко человъкъ въ гробъ положень бысть, и яко богъ олтарь язычьскыл ичеркве освяти (СП); что сътворимъ галильяниу сему Иисусу яко <..> старечьская преданья в посмьхь ${ }^{27}$ положиль есть, а рыбарь тивериядьскаго езера невъгласы сущая же по себъ нынь водить; изъ изьркве продающих овца и голуби изгонить, а мытари и грьшники приимая в жертвеник въводить; на архиерья и книжники господьскы грозится, фарисъемь с левгиты акы властель прътить <..>, а блудницъ от любодъищь отводя святы нарицая глаголеть (СС).

6.3. Сложной с точки зрения расположения глагола и дополнения является ситуация, когда на той же семантике сопоставления / противопоставления основана

25 Аналогичная ситуация представлена в «Пчеле», где при сопоставлении и противопоставлении достаточно часто фиксируется порядок OV [Пичхадзе, Родионова 2011: 142-144]. Исследователи неоднократно отмечали, что антитеза является одной из излюбленных фигур у Кирилла Туровского.

${ }^{26}$ Правильным является чтение Толст-39 многи. Речь идет об Овчей купели, в которой многие страждущие окунались, но единицы получали исцеление.

27 Исправлено в соответствии с чтением Толст-39; в Увар-589 ошибочно в помысльхъ. 
большая часть текста, как в «Слове памяти отцов Никейского собора». Чем крупнее период, тем больше вероятность того, что в нем окажется одна или более чем одна группа «личная форма глагола + прямое дополнение» с препозицией глагола. Именно это имеет место во вступлении «Слова памяти отцов Никейского собора». Оно частично построено на мотивах паримий, читающихся на великой вечерне накануне празднования памяти 318 отцов-участников I Вселенского Никейского собора, на котором было осуждено арианство. Речь в них идет об истории Авраама, и в связи с этим в Слове обыгрывается символическое значение числа 318 (см. Быт. XIV14-19). Кирилл Туровский проводит параллель между ветхозаветными событиями и событиями церковной истории, сначала говоря об Аврааме, потом о святых отцах.

В начале, несмотря на семантику сопоставления, в постпозиции находится не глагол, а дополнение: но Аврамъ телесную створи побъду видимомъ воемъ, а си къ духовнъи сдольша рати невидимыя побъдиша бъсbl. Такой порядок слов продиктован дистантным расположением атрибута, при котором существительное (в данном случае являющееся прямым объектом) занимает конечную позицию 28. Аналогичные случаи есть и в других приведенных выше и ниже примерах (вселестьное искоренисте тернье, слатку подавають воню, адьская разрушить скровища, съмьртное уторже ядро). Поскольку порядок слов в группе «личная форма глагола + прямое дополнение» допускает значительную вариативность, а в именной группе с дистантным расположением атрибута является достаточно жестким, в постпозиции оказывается дополнение. Таким образом, фактор наличия дистантно расположенного атрибута оказывает влияние на постановку дополнения, поскольку место глагола в данном случае фиксировано ${ }^{29}$.

Далее в тексте отмечается постпозиция глагола. Как и в примерах выше, для наглядности парные смысловые единицы даны через знак тире и помещены в одном абзаце:

Аврамъ 5 иъсарь съ силами ихъ побъди и Лота сьлнова своего възврати; а си вся еретикь духовныли иськоша мечи и иерковь Христову възвратиша от кумирослуженья;

Аврама възвращуьшася от съча ияъсари ${ }^{30}$ благослови иерьи божии Мелхиседек и хльбъ с виномь изнесе; - а святии наши отци по низложеньи и по проклятьи богоборець еретикъ самъ богъ отець благослови и прослави и святьи духь вънча и освяти.

${ }^{28}$ Подробнее о порядке слов в именной группе при дистантном расположении атрибута в Словах Кирилла Туровского см. [Макеева 2018: 101-102; 2019: 210-213].

29 Если не ограничиваться прямым дополнением, то есть формой винительного падежа существительного, количество подобных примеров увеличивается.

30 Все начало фразы приведено по Толст-39; таким оно было и в аутентичном тексте Кирилла. В Увар-589 здесь неудачное изменение падежных форм, в результате которого понимание смысла затруднено. 
6.4. Еще один период, основанный на противопоставлении, находится в «Слове о снятии тела Христова с креста»:

онъ послушавъ свъта вражия въсхоть быти богъ и проклять бысть; - се же послушавъ отияа бысть сы богъ и человъкъ да змия погубить и иеловька cnacemb;

онъ простеръ руцьъ къ древу възъбраньному съмьртное уторже ядро и бывъ рабъ грьху сниде от едема въ адъ; - Христось же на крьсть руйь простерь осужения грвховнаго и от съмьрти человька свободи.

7. Остальные факторы, от которых зависит расположение личной формы глагола и прямого дополнения, хотя и встречаются нечасто, могут существенно повлиять на количественные показатели словопорядка в группе «личная форма глагола + прямое дополнение».

7.1. Первый среди них - наличие обобщающего понятия, которое дважды встречается в «Слове о слепце». В одном случае период устроен очень просто: после общего понятия всего человъка перечисляются разные исцеленные Христом люди: ... всего человька здрава створивъ: раслабленаго въстави, хромыя убыстри, прокаженья очисти, слукия исправи, глухия и ньмыл добрь сльишаща и глаголивь створи, сухорукьля укрьпи, бъсы от чловъкъ прогна, сльпьля просвъти. Здесь нельзя исключать влияния «Слова о законе и благодати» мт. Илариона, к которому, возможно, восходит фрагмент, хотя первоисточником с большой долей вероятности следует считать Евангелие от Матфея X $8^{31}$.

Другой случай использования обобщающего понятия с последующим перечислением нескольких объектов из-за большого размера фрагмента на первый взгляд не очевиден. Схематически он выглядит следующим образом: ... не бысте избивали посланыхъ к вам от Бога пророкъ... Иеремию каменьемь побисте... Исаю древяною претросте пилою... Иосию поразисте в Самарии... великаго Иезекиля прольясте кровь. Сложность заключается в том, что предикации с прямым дополнением отделены друг от друга и от обобщающего понятия пророкъ другими предикациями, включая цитаты, так что нелегко понять, как организован период и почему глагол находится в постпозиции. Ср. последнее словосочетание прольясте кровь, которое не тождественно трем другим и потому имеет другой порядок компонентов.

8. В начале произведения или структурно-смысловой части личная форма глагола и прямое дополнение встречаются редко. Такая предикация начинает «Слово о слепце»: Милость божию и человьколюбие господа нашего Иисуса Христа, благодать же Святаго Духа... сказаю вам. Находящиеся в препозиции дополнения, с одной стороны, называют тему произведения, в основу которого положена евангельская история об исцелении Христом слепорожденного; с другой стороны, они выступают как тема в плане актуального членения предложения.

31 Перечень исцеленных Христом у Илариона меньше, но расположение дополнения и гла-

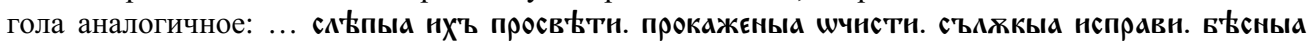

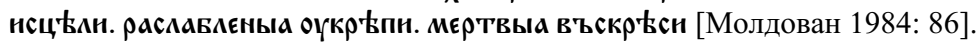


В «Слове о снятии тела Христова с креста» имеется одно и то же словосочетание с разным порядком компонентов: Нынъ же Иосифа благообразного с мюроносицами похвалимъ, послужившаго по распятьи твлу Христову; Похвалимь нынь Иосифа приснопамятнаго, благообразнаго же и досточюднаго. В первом случае после предисловия в текст вводится сквозной персонаж, заявленный в названии; далее через него как главное действующее лицо переданы изложенные в произведении события. Дополнение здесь называет тему, личная форма глагола - рему. Во втором примере группа с препозицией глагола начинает также упомянутую в названии похвалу Иосифу — новую часть произведения ${ }^{32}$. Такой порядок компонентов, с одной стороны, является обычным; с другой стороны, дополнение, которое к тому же имеет несколько атрибутов в постпозиции, выступает в роли ремы.

9. Конструкций с двойным винительным (accusativus duplex) в Словах Кирилла Туровского мало, поэтому можно сделать только отдельные наблюдения над порядком слов в этих случаях, не претендующие на выявление закономерностей. Такие конструкции интересно сопоставить с другими, где одно из дополнений имеет форму творительного падежа.

9.1. В единственной группе с глаголом створити оба существительных находятся в препозиции: благовърныя люди престоль богови вмъстилище святому духу створиша (СЦ); ср.: да богомь человька створю (СР), где глагол также находится после обоих дополнений ${ }^{33}$.

9.2. Глаголы речи чаще оказываются между существительными-дополнениями ${ }^{34}:$ агньия глаголю иже от языкъ кроткья лююи (СФН); люди же наричет вся

32 Аналогичные предикации, в которых такая же глагольная форма находится в препозиции, есть в других произведениях Кирилла. В «Слове о слепце» она присутствует в начале заключительной части текста - в похвале слепцу: похвалимъ помилованаго богомь человька. В «Слове на Фомину неделю» предикация похвалимъ красную сию недълю новую как будто тоже начинает новый смысловой фрагмент.

${ }_{33} \mathrm{~B}$ текстах имеется небольшое количество конструкций с глаголом (с)творити, прямым объектом, выраженным неличным местоимением или существительным (именем собственным), и прилагательным в винительном падеже с общим значением «сделать кого-л. каким-л.». Глагол

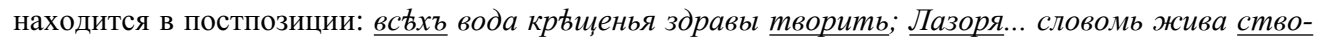

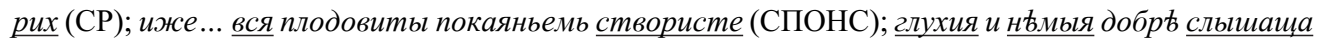
и глаголивы створи $(\mathrm{CC})$. Если в качестве прямого объекта выступает личное местоимение, то сохраняется такое же расположение глагола, а местоимение вместо обычной постпозиции оказывается в препозиции: ...иже тя иъва створи (придаточное), ... иже мя иъла створи (придаточное) (CР); чюжа его собъ створиша друзи и знанья (СС). Иначе в следующем случае, где постпозицию прилагательного можно объяснить рематизацией: никтоже васъ умъ мнъ дарова, нъ же мя створи иъла (СР). Ср. предикации с другими глаголами: въскрьсша ㅆ иㅎхомъ (СП); мертва ли себе нареку, жива ли себе помышляю (СР).

${ }_{34} \mathrm{~B}$ древнерусских памятниках в словосочетаниях с двойными косвенными падежами порядок слов не является фиксированным, хотя препозиция первого косвенного падежа, обозначающего тему, значительно преобладает [Глинкина 1968: 148 ]. Расположение глагола в цитируемой работе не рассматривается, но по приведенным схемам видно, что он может находиться в препозиции, постпозиции и между существительными. 
языкьи, грьхъ своихъ ради сведеныя въ адъ, а чада наричеть иже в законь скончашася (СВ); стариа бо язычьския намьнуеть люди 'под старцами подразумевает язычников'(СЦ) $)^{35}$; ср. следующий пример с постпозицией глагола: младеньци же вся хрестьяны прообрази иже ничтоже пытають о Христь 'детьми же всех христиан представил, которые ничего не выпытывают о Христе’ (СЦ) ${ }^{36}$.

9.3. Место существительного прямого объекта может занимать местоимение: землю ли тя благоцвътущю нареку; святителя тя и старьишину прозову $(\mathrm{CCTXК)})^{37}$; господа мя нарече $(\mathrm{CФН).} \mathrm{Наряду} \mathrm{с} \mathrm{такими} \mathrm{словосочетаниями} \mathrm{Кирилл}$ Туровский использовал конструкции с существительным в творительном падеже: небомь ли тя прозову; апостоломь ли тя именую; священомученикомъ ли тя нареку (Там же). Оба типа словосочетаний имеют один и тот же порядок слов: существительные (или существительное) находятся в препозиции, а глагол - в постпозиции. Местоимение, будучи энклитикой, занимает срединную позицию, и это один из немногих случаев, когда оно располагается перед глаголом. Данные предикации, чередуясь с другими, являются опорными в структуре периода, который составляет часть похвалы Иосифу Аримафейскому в «Слове о снятии тела Христова с креста».

10.1. Среди групп «личная форма глагола + прямое дополнение» в риторических произведениях Кирилла Туровского есть небольшое количество связанных словосочетаний и словосочетаний figura etymologica. В последних глагол находится в постпозиции, а дополнение в препозиции: се тьло сьмьрть умьртви и тварь всю истльвшюю обнови (СП); сниде самь господь в адъ и попра бъсовьское ияарьство крьстомь и съмьрть умьртви (Там же); пьсньныл глагольг глаголеть (СВ); праведныл судъ судите (СР). Однако в придаточном предложении встречается и обратный порядок: свъщаша свьть золь (СП).

10.2. В связанных словосочетаниях порядок следования дополнения и глагола разный: уметы створи (ССТХК); прикланяють ... слухи, приклоните... слухи, укланяете слухи (СПОНС) ${ }^{38}$; въру яти $(\mathrm{CФН})^{39}$. Первое словосочетание, имеющее значение 'пренебречь', встречается, как кажется, только у Кирилла Туровского (еще раз в его же «Слове в неделю цветоносную») $)^{40}$. Словосочетания прикланяти слух(u) и приклонити слух(u) известны по разным источникам и почти везде, как

${ }^{35}$ Пример приведен по списку Писк-92 (РГБ, собр. Пискарева, № 92, XV в.), близкому к старшему неполному списку Толст-39. Очевидно, таким было чтение протографа. В других рукописях имеет место вторичная замена прилагательного (в Увар-589: стария бо всячьскыхъ...) или глагола (в Чуд-20: послъдують), при которых фраза становится непонятной.

${ }^{36}$ Пример приведен по Писк-92, чтение которого кажется наиболее исправным.

37 По спискам это чтение варьируется; пример приведен по Чуд-20.

38 В Толст-39 отклоняете слухы.

39 В монологе Христа в заключительной части произведения императив въру ими чередуется с императивами не буди невъренъ, въруи, вижь; в ответной речи Фомы использованы глагольные формы върую и вижю.

${ }^{40}$ См. [Срезневский 1989: 1205]. В «Слове в неделю цветоносную» в Увар-589 находится причастие уметы створивше, а в Писк-92 и Чуд-20 - личная форма глагола уметы створиша. 
и в сочинении Кирилла, глагол находится в препозиции ${ }^{41}$. В очень распространенном фразеологизме въру яти именно такой порядок компонентов отмечается в разных памятниках; см. [Пичхадзе, Родионова 2011: 130-132].

Вместе со связанными словосочетаниями следует рассматривать клише, в которых глагол находится в постпозиции: смьрть попра; ада попра (СЦ); живот дарова $(\mathrm{CП})$.

10.3. К клишированным можно отнести словосочетание (c)mворити чудо, которое очень часто встречается в памятниках. С разным порядком компонентов оно пять раз употреблено в произведениях Кирилла Туровского. Дважды глагол находится в препозиции, причем во втором примере - в придаточном определительном, где чаще отмечается обратный порядок: по всеи Палестинь створи чюдеса и не въровахуть ему (СР); в нихже бъ и богоблаженыи Спиридонь, имже ство$\underline{p u}$ богъ чюдо въ сборь (СПОНС). Один случай постпозиции глагола объясняется семантикой сопоставления: в жидъхъ бо чюдеса створи, а языкомъ благодать u спасение дарова (СЦ); второй — наличием при дополнении слова со значением большого количества: ... многа ины чюдеса створи (СПОНС). Третий случай постпозиции глагола объяснить трудно, если только не предполагать его рематизации: по въпросъх своихъ ученик дивно чюдо творить (СС).

11. Тенденцию к постановке в той или иной позиции демонстрируют некоторые лексемы. Так, дополнения Христос и бог преимущественно находятся в препозиции ${ }^{42}$ о о своемь бо неради животь да Христа приобрящеть; ты же радуяся на своею руку Христа бога носиль еси; ты же тогда радуяся на своею руку бога носяше (ССТХК); да и мы, братье, того Иисуса Бога нашего прославимь (СР); пастьри свиряюще веселиемь Христа хвалять; да и учители Христова стада о всъхъ молящеся Христа славять; дьлатели с надежею тружающеся плододавия Христа призывають (СФН); с нимь веселящеся Христа славять (СС). Отступления от такого расположения представлены в четырех предикациях: 1-3) прославили есте на земли Христа сына божия, и ть прославиль есть васъ на земли (СПОНС); и прославиша Иисуса Христа сына божия святи наши отцуи, и утвердиша иььрковь <...>, и научиша вся вьровати (Там же); сбор же святыхъ отець 300 и 18 радости исполнишася и прославиша Бога и праздновати повельиа (Там же). Здесь можно видеть рематизацию объекта, обозначенного прямым дополнением, а в первых двух примерах - еще и в сочетании с параллелизмом; 4) знаимъ Xpиста Бога Спаса нашего, емуже слава... (СФН). Это заключительная фраза произведения, вполне традиционная по своему построению.

Дважды в функции прямого дополнения встретилось существительное госnодb: апостоли же днесь на Сионь вшедше к нему познаша господа; свою кождо поюще пьснь славять zоспода $(\mathrm{CФН).} \mathrm{Хотя} \mathrm{оба} \mathrm{раза} \mathrm{оно} \mathrm{расположено} \mathrm{в} \mathrm{постпозиции,}$

${ }^{41}$ В СДЯ для словосочетания прикланяти слух при двух случаях порядка VO один раз (в «Пчеле») отмечен порядок OV; для приклонити слух порядок VO представлен в большом количестве источников, а порядок ОV - один раз [СДЯ 8: 452, 453].

42 Такое же расположение слова богъ отмечается в «Пчеле» и «Житии Андрея Юродивого»; см. [Пичхадзе, Родионова 2011: 137, 145]. 
причем в той части произведения, где любое другое дополнение находится в препозиции (об этом см. выше), о тенденции постановки слова господь из-за малочисленности примеров судить трудно.

12. На постановку дополнения в препозиции влияет наличие относящегося к нему слова со значением большого количества; см. об этом [Пичхадзе, Родионова 2011: 155].

В Словах Кирилла Туровского есть один такой случай; предикация является определительным придаточным предложением: ... иже Костянтина цъсаря от проказы очисти и многа ины чюдеса створи (СПОНС). В другой предикации, также при препозиции дополнения, имеется определение со значением малого количества: мало нъчто скажемъ а [так!] поновлении въскрьсения (СФН).

13. Порядок OV отмечен в вопросительных предложениях с относящимся к дополнению вопросительным местоимением кыли или какъ: какы воня възлью на твое святое тьло; кыля ли гробнья пㅎсни исходу твоему въспою; кую похвалу створимъ достоину твоего блаженьства (ССТХК).

14. Как и в именной группе с атрибутом, так и в группе «личная форма глагола + прямое дополнение» нередко встречается дистантное расположение компонентов. В зависимости от того, что именно находится между дополнением и глаголом, можно выделить несколько типов дистантных словосочетаний.

14.1. Первый тип: личная форма глагола и дополнение разделены атрибутивным словосочетанием (в том числе являющимся несогласованным определением), иногда - причастием с зависимым словом: терние прельсти вражия искоренить $^{43} ;$ да разрьиить от узъ дьяволь человьки; образъ своея служьбы предаль еси; внушаите моихь слезъ рыдание; кивоть с божиемь словомь принесе; видите божия смотрения таиньство; гробнья пьсни исходу твоему въспою (ССТХК); ту полагаху жертвеныхъ овечь утробьг; зль расточихъ даемо в раи богатьство; повьдаху сына божия силу; грьси мои вся уды телеси моего раслабиша (CР); п्мяну бо блаженьи иъсарь пророчьское слово; полну изьрковную мрежю къ иьркви Христовъ привлекосте (СПОНС). Изредка дистантное расположение компонентов в именной группе с атрибутом и в словосочетании глагола с дополнением воз-

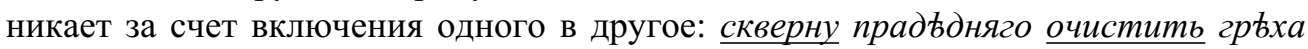
(CCTXK).

14.2. Второй тип: личная форма глагола и дополнение разделены относящимися к глаголу (иногда - к дополнению) словами или словом (кроме относящегося к дополнению атрибута): да адова врата и верея от основания скрушить, подажь всьм намь твоя помощь, видьста утрь во гробъ два аньгьла; гвоздиньныя язвь на руку и на ногу показаеть Фомь (ССТХК); тебъ всю тварь на работу сътворих (СР); своя раздаваеть комуждо дарыл; посылаеть апостоломь святыи свои духъ (СВ); прозрьвшаго на судище влекуть; изгонять от сборища помилованаго богомь; Иеремию каменьемь побисте (СС); мрвжю ловитвы обрьтають; обнажи предо

43 Следует обратить внимание на то, что в этом примере и в группе с атрибутом, и в группе с дополнением представлен менее частотный порядок: атрибут находится в постпозиции, а дополнение - в препозиции. 
всъми своя ребра; понавляемъ побъдныи (по Толст-39) на врагы день; исповъдаите первое о мне исаино писание (СФН); испросите душамь нашим отпусть грвховъ; да отверзеть намь врата (СПОНС).

14.3. Третий тип: личная форма глагола и дополнение разделены более чем одной группой слов или даже предикацией: показаеть своего божества исконьнаго дъла образъ (СС), да Адама от ада съ Евгою падша преступлениемь пакы въведеши в раи; божие тьло с Никодимомь въ плащаницю с вонями обивъ положиль еси (ССТХК); изльимы яко мюро на главу его вьру и любовь; уготоваимъ яко и горлицю смьрениемь душа наша (СЦ); святыя же пророки и преподобныя праведники съ собою на небеса въ святыл въводить градъ; послю яко объмахъ вамъ иного параклита; даеть отию принесенную имь жертву (СВ); рыбары тивериядьскаго езера, невъгласы сущая же, по себъ нынъ водить (СС); възлияхь на язвы его моея крови вино и масло (СР); святии наши отщи по низложеньи и по проклятьи богоборець еретикъ самъ богъ отець благослови и прослави (СПОНС); жертву за спасение всего мира принесе (СП).

Во всех трех типах словосочетаний с дистантным расположением личной формы глагола и прямого дополнения нет фиксированного места компонентов: и глагол, и дополнение могут находиться в препозиции и постпозиции. Большая свобода расположения компонентов таких словосочетаний коррелирует с общим незначительным преобладанием препозиции глагола. В именных группах с атрибутом при общем существенном преобладании препозитивного употребления атрибута наблюдается его постановка в препозиции и в дистантных словосочетаниях.

15. В целом в риторических произведениях Кирилла Туровского в группе «личная форма глагола + прямое дополнение» препозиция глагола, которая представляется его нейтральным, немаркированным расположением, лишь незначительно преобладает над постпозицией. Постановка глагола после дополнения обусловлена рядом факторов: рематизацией глагольной формы, построением соседних предикаций и целых периодов с использованием параллелизма и хиазма и их довольно сложных комбинаций, семантикой противопоставления и сопоставления, местонахождением группы «личная форма глагола + прямое дополнение» в начале текста или структурно-смыслового фрагмента, наличием общего понятия и еще несколькими частными более или менее значимыми факторами. Одни из них актуальны для разных памятников церковнославянского языка; использование других факторов, особенно таких как наличие обобщающего слова и построение отдельных предикаций и целых периодов, характерно для Слов Кирилла Туровского. Очень хорошо авторская установка видна на функционально схожих пассажах - обращениях к пастве, которые демонстрируют разные способы построения текста, в том числе реализуемые в порядке расположения глагольной формы и дополнения. Порядок компонентов в группе «личная форма глагола + прямое дополнение» оказывается гораздо менее жестким по сравнению с расположением атрибута в именной группе. Это проявляется также в разных типах словосочетаний с дистантным расположением дополнения, которое может находиться как в препозиции, так и в постпозиции, тогда как атрибут в таких же словосочетаниях стоит в препозиции. 


\section{Источники}

СДЯ 8 - Словарь древнерусского языка (XI-XIV вв.). Т. 8. М., 2008.

Евангелие от Иоанна - Евангелие от Иоанна в славянской традиции / Изд. подгот. А.А. Алексеев, А. А. Пичхадзе, М. Б. Бабицкая и др. СПб., 1998.

Молдован 1984 - Молдован А. М. Слово о законе и благодати Илариона. Киев, 1984.

\section{Литература}

Бегунов Ю.К. К стилистике торжественного красноречия: Кирилл Туровский и Григорий Цамблак // Търновска книжовна школа. Велико Търново, 1971. С. 39 51.

Виноградов В.П. Уставные чтения. Вып. III. Очерки по истории греко-славянской церковно-учительной литературы. Сергиев Посад, 1915.

Глинкина Л.А. Вторые косвенные падежи // Сравнительно-исторический синтаксис восточнославянских языков. Члены предложения. М., 1968. С. 96-150.

Двинятин Ф.Н. Лингвопоэтический анализ Торжественных Слов святого Кирилла Туровского. Автореферат дисс. < ..> канд. филол. наук. СПбГУ, 1995.

Ковтунова И. И. Порядок слов в русском литературном языке XVIII - первой трети ХIX в. М., 1969.

Ковтунова И.И. Современный русский язык. Порядок слов и актуальное членение предложения. М., 1976.

Макеева И.И. Порядок слов в атрибутивных словосочетаниях в риторических произведениях Кирилла Туровского // Русский язык в научном освещении. 2018. №2 (36). С. 87-104.

Макеева И.И. Порядок слов в атрибутивных словосочетаниях в «Слове о снятии тела Христова с креста» Кирилла Туровского // Славянское и балканское языкознание. Палеославистика-2. М., 2019. С. 199-216.

Пичхадзе А.А., Родионова А.В. О порядке слов в сочетаниях «личная форма глагола - прямое объектное дополнение» в древнерусском языке // Русский язык в научном освещении. 2011. № 1 (21). С. 127-161.

Рогачевская Е. Б. Библейские тексты в произведениях русских проповедников // Герменевтика древнерусской литературы X-XVI вв. М., 1992.

Сухомлинов М. И. Рукописи графа А.С. Уварова. Т. 2: Памятники словесности. Вып. 1. СПб., 1858. С. XIII-LXI. 


\section{Irina I. Makeeva}

Vinogradov Russian Language Institute of the Russian Academy of Sciences

(Moscow, Russia)

irinamakeeva2007@mail.ru

\section{ON WORD ORDER IN VERB-DIRECT OBJECT COMBINATIONS IN THE SERMONS OF CYRIL OF TUROV}

The article discusses position of the verb and object in three Sermons of Cyril of Turov, an Old Russian writer from the $12^{\text {th }}$ century (based on a $14^{\text {th }}$-century manuscript). Placing the verb at the beginning is characteristic of the author's texts, but examples of the verb being placed in final position are also frequent. This type of positioning of verb and object depends on several factors, which are discussed in this article.

Keywords: sermons of Cyril of Turov, Old Russian language, syntax, word order, verb, object.

\section{References}

Begunov Yu. K. K stilistike torzhestvennogo krasnorechiya: Kirill Turovskiy i Grigoriy Tsamblak. T"rnovska knizhovna shkola. Veliko T"rnovo, 1971. S. 39-51.

Vinogradov V.P. Ustavnye chteniya. Vyp. III. Ocherki po istorii greko-slavyanskoy tserkovno-uchitel'noy literatury. Sergiev Posad, 1915.

Glinkina L.A. Vtorye kosvennye padezhi. Sravnitel'no-istoricheskiy sintaksis vostochnoslavyanskikh yazykov. Chleny predlozheniya. Moscow, 1968. S. 96-150.

Dvinyatin F.N. Lingvopoeticheskiy analiz Torzhestvennykh Slov svyatogo Kirilla Turovskogo. Thesis SPbGU. St. Petersburg, 1995.

Kovtunova I.I. Poryadok slov v russkom literaturnom yazyke XVIII - pervoy treti XIX v. Moscow, 1969.

Kovtunova I. I. Sovremennyy russkiy yazyk. Poryadok slov i aktual'noe chlenenie predlozheniya. Moscow, 1976.

Makeeva I.I. Poryadok slov v atributivnykh slovosochetaniyakh v ritoricheskikh proizvedeniyakh Kirilla Turovskogo. Russkiy yazyk v nauchnom osveshchenii. 2018. №2 (36). S. 87-104.

Makeeva I.I. Poryadok slov v atributivnykh slovosochetaniyakh v «Slove o snyatii tela Khristova s kresta» Kirilla Turovskogo. Slavyanskoe i balkanskoe yazykoznanie. Paleoslavistika-2. Moscow, 2019. S. 199-216.

Pichkhadze A.A., Rodionova A.V. O poryadke slov v sochetaniyakh «lichnaya forma glagola - pryamoe ob"ektnoe dopolnenie» v drevnerusskom yazyke. Russkiy yazyk $v$ nauchnom osveshchenii. 2011. № 1 (21). S. 127-161.

Rogachevskaya E. B. Bibleyskie teksty v proizvedeniyakh russkikh propovednikov. Germenevtika drevnerusskoy literatury X-XVI vv. Moscow, 1992.

Sukhomlinov M. I. Rukopisi grafa A. S. Uvarova. T. 2: Pamyatniki slovesnosti. Vyp. 1. St. Petersburg., 1858. S. XIII-LXI. 